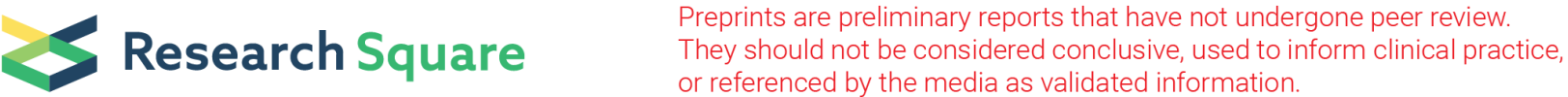

\section{Quantitative assessment and impact of thermal treatment on quality of Holstein dairy cattle colostrum immunoglobulin and viscosity}

Abdulwahed Ahmed Hassan ( $\sim$ abdulwahed-ahmed.hassan@vetmed.uni-giessen.de ) Justus-Liebig-Universitat Giessen Fachbereich Veterinarmedizin https://orcid.org/0000-0001-90882905

Sebastian Ganz Justus Liebig Universitat Giessen

Florian Schneider Justus Liebig Universitat Giessen

Axel Wehrend Justus Liebig Universitat Giessen Izhar U.H. Khan Agriculture and Agri-Food Canada

Klaus Failing Justus Liebig Universitat Giessen

Michael Bülte Justus Liebig Universitat Giessen

Amir Abdulmawjood

Tierarztliche Hochschule Hannover

\section{Research article}

Keywords: Holstein dairy cattle colostrum, colostrometer, digital \%Brix refractometer, thermal treatment, dynamic viscosity

Posted Date: August 13th, 2019

DOI: https://doi.org/10.21203/rs.2.12753/v1

License: (c) (1) This work is licensed under a Creative Commons Attribution 4.0 International License. Read Full License 


\section{Abstract}

\section{Background}

Bovine postpartum colostrum delivers a vital source of immunoglobulins (Igs) and other non-specific immune factors for passive transfer of immunity to newborn calves. Heat treatment of colostrum is an effective practice to reduce potential pathogens that can be transmitted to the newborn calves. Therefore, there is a need to determine optimized temperature and time that can minimally change IgG concentration and the viscosity (consistency) of colostrum. In order to preserve the quality and value of bovine postpartum colostrum, this study aimed to determine the $\mathrm{IgG}$ concentration, influence of different thermal treatments on the quality of colostrum and other properties including viscosity, fat and color.

Results

A total of 40 German Holstein dairy cattle first colostrum samples, collected after birth, were evaluated for color gradation, fat (\%), colostrum IgG (mg mL-1), IgG (\%Brix) and refractive index (nD) concentration, visual and dynamic viscosity and impact of different treatments $\left(60^{\circ} \mathrm{C} / 60 \mathrm{~min} ; 63.5^{\circ} \mathrm{C} / 30 \mathrm{~min}\right.$ and $72.0^{\circ} \mathrm{C} / 15 \mathrm{~s}$ ) on the viscosity. The color was graded from white-pale yellow to yellow and dark-yellowish,

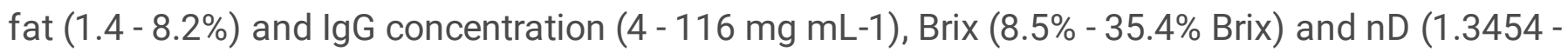
1.3905), respectively. The visual viscosity of first colostrum was classified into watery, liquid and thick consistency, whereas the dynamic viscosity and treated colostrum ranged from $<10$ to 219 and $<10$ to 3066 centipoise (cP), respectively. The consistency of treated samples were classified into liquid, thick and solid with significant change in the dynamic viscosity.

\section{Conclusion}

Data revealed significant variation in the IgG values where both measurement methods showed high congruence with IgG classification. Due to the fact that individual IgG values were disparate, this significantly affected the colostrum consistency with different treatments. The study showed that colostrum containing IgG $\leq 80 \mathrm{mg} \mathrm{mL}-1$ and $\leq 68 \mathrm{mg} \mathrm{mL}-1$ treated at $60^{\circ} \mathrm{C}$ for $60 \mathrm{~min}$ and $63.5^{\circ} \mathrm{C}$ for 30 min showed a slight to moderate change in the consistency which suggests that these two temperatures and lengths of time that had a minimal impact on the consistency can be used to pasteurize colostrum.

\section{Background}

Bovine colostrum is the first milk secretion produced by the mammary gland during the first few days after parturition. First colostrum rich in immunoglobulins (Igs) protects newborn calves against infectious diseases through passive transfer of immunity (1). During pregnancy, the maternal and fetal blood supplies are separated, the bovine syndesmochorial placenta preventing transmission of Igs into the uterus and calves are born without antibodies which is known as agammaglobulinaemia (2). Therefore, postpartum colostrum delivers a vital source of Igs and non-specific immune factors for passive transfer of immunity to the newborn calf. Colostrum also contains important ingredients including maternal 
leukocytes, macrophages, $\mathrm{T}$ and $\mathrm{B}$ lymphocytes, neutrophils, growth factors, cytokines, nonspecific antimicrobial factors, a rich source of nutrients and hormones for growth promotion and development of newborn calves in their first weeks of life. (2-5). After parturition, newborn calves need to ingest 3-4 liters of high-quality colostrum containing $\geq 50 \mathrm{mg} \mathrm{mL}^{-1}$ of $\mathrm{IgG}$ within the first $6 \mathrm{~h}$ after birth to protect them from pathogens until their own immune system is developed $(2,6)$. Insufficient consumption of colostrum e.g., an IgG level less than $10 \mathrm{mg} \mathrm{mL}^{-1}$ in calf blood serum leads to a failure of transfer of passive immunity (FTPI), which increases susceptibility to pathogens and is subsequently associated with an increased risk of morbidity and mortality (7-9). Certain management factors contribute to preventing FPTI. Firstly, newborn calves should receive an adequate amount of high quality first-milking colostrum containing $\geq 50 \mathrm{mg} \mathrm{mL}^{-1}$ of IgG. Secondly, newborn calves should be fed colostrum within 1$2 \mathrm{~h}$ after parturition containing a low bacterial count $\left(<105 \mathrm{CFU} \mathrm{mL} \mathrm{L}^{-1}\right)(3,10)$. However, colostrum management needs considerable improvements to be undertaken to develop a specific program for newborn calves on dairy farms that leads to a reduction in the occurrence of FTPI (8). Due to various factors, bovine colostrum quality varies considerably in IgG concentration. Therefore, estimating the quality of first-milking colostrum on farms by measuring the specific gravity or IgG concentration prior to feeding calves is a useful management tool to improve calf health status $(3,11-13)$. On farms, there are diverse indirect tools used such as hydrometers or colostrometers as well as visual and digital Brix refractometers $(14,15)$. In contrast, direct methods including radial immunodiffusion (RID) assay, enzyme-linked immunosorbent assay (ELISA), infrared spectroscopy (IR), turbidimetric immunoassay (TIA) and enzymatic assays like split trehalase immunoglobuline $G$ assays for estimating Ig $G$ concentration in colostrum and calf serum have been exclusively applied as the gold standard methods in diagnostic laboratories (16-21). Many studies have estimated the quality of immunoglobulin of bovine colostrum at postpartum milking $(19,22)$. Previously, numerous studies presumed the influence of heat treatment and pasteurization processes on the consistency, stability of Ig and reduction or elimination of bacteria $(11,23-25)$.

The present study was designed to evaluate color, visual and dynamic viscosity, fat percentage and IgG concentration of first colostrum of Holstein dairy cattle taken immediately after parturition and the impact of different thermal treatments on its viscosity. Subsequently, the study aimed to establish an optimal heat process (temperature and time) that can have a minimal impact on the viscosity and IgG concentration.

\section{Results}

\section{Color and fat content}

The color of each fresh colostrum sample of German Holstein dairy cattle was visually estimated. Of the total 40 samples, the color of 37 ranged from white-pale yellow to yellow and dark-yellowish. The other three samples collected from healthy dairy cattle showed a slightly pinkish color due to the presence of blood as a result of hemorrhage per diapedesis. The fat concentration of colostrum samples ranged from 
1.4 to $8.8100 \mathrm{~g}^{-1}$ (Table 1) with a distribution pattern of $17(42.5 \%)$ samples that had high-fat (ranging from 7.0 to $8.8100 \mathrm{~g} \mathrm{~g}^{-1}$ ), followed by $11(27.5 \%)$ samples with medium-fat (ranging from 4.5 to 6.2100 $\mathrm{g}^{-1}$ ) and 12 samples (30\%) with low-fat (ranging from 1.5 to 4.0100

$\mathrm{g}^{-1}$ ) concentration. Hence, in the present study, no significant correlation was found between the fat and color gradation nor between fat and $\operatorname{lgG}\left(\mathrm{mg} \mathrm{mL}^{-1}, \%\right.$ Brix and $\mathrm{nD}$ ) concentrations (Table 2).

\section{IgG concentration}

The IgG concentration ( $\mathrm{mg} \mathrm{mL}^{-1}$ ) of fresh colostrum samples using a colostrometer ranged from 4.0 to $116 \mathrm{mg} \mathrm{mL}^{-1}$ (Table 1). Based on the cut-point ( $\left.\leq 50 \mathrm{mg} \mathrm{mL}^{-1}\right), 15$ (37.5\%) and 25 (62.5\%) samples were classified as low and high quality colostrum, respectively. The relationship between IgG

( $\mathrm{mg} \mathrm{mL}^{-1}$ ) concentration and visual viscosity showed that the majority of the samples $(n=13 ; 92.3 \%)$ with low IgG concentration had a watery consistency compared to $15(60 \%)$ and ten $(40 \%)$ samples with a high IgG concentration which had liquid and thick consistencies, respectively (Table 3 ). The IgG \%Brix of fresh colostrum samples ranged from 8.5 to 35.4 (Table 1). According to the \%Brix cut-point $(\leq 20$ \%Brix), 17 (42.5\%) and 23 (57.5\%) samples were classified as low and high quality colostrum, respectively. Furthermore, the IgG nD values of fresh colostrum samples ranged from 1.3454 to 1.3905 (Table 1$)$. Based on the $\mathrm{nD}$ cut-point $(\leq 1.3596)$, a similar per cent $(42.5$ and $57.5 \%)$ of samples were classified as low and high quality colostrum. The relationship congruency between $\operatorname{lgG}\left(\mathrm{mg} \mathrm{mL}^{-1}\right)$ and IgG \%Brix revealed that 38 (95\%) samples were in agreement with the two methods. The statistical relationship between IgG $\left(\mathrm{mg} \mathrm{mL}^{-1}\right)$ and \%Brix revealed significant coefficients; $(r)$ was 0.894 between $\operatorname{lgG}\left(\mathrm{mg} \mathrm{mL}^{-1}\right)$ and $\mathrm{nD}$ was 0.887 and 0.991 between \%Brix and $\mathrm{nD}$, respectively (Table 2$)$. The linear correlation and regression of these values are illustrated in Fig. 1 (Panels A-C).

\section{Visual and dynamic viscosity}

The visual viscosity of fresh colostrum was categorized as watery $(n=14 ; 35 \%)$; liquidy $(n=17 ; 42.5 \%)$ and thick $(n=9 ; 22.5 \%)$, respectively (Table 3 ). However, dynamic viscosity of fresh colostrum ranged from 4.9 to 219 centipoise (cP) (Table 1). Overall, viscosity of colostrum was impacted by increasing the concentration of fat, protein and IgG, but no significant correlation between the fat concentration and visual as well as dynamic viscosity was observed. For instance, the 17 samples classified as high-fat (7.0 - $\left.8.8100 \mathrm{~g}^{-1}\right)$ concentration were classified into three categories: watery $(n=9)$, liquidy $(n=6)$ and thick $(n=2)$, respectively.

The statistical analyses revealed a significant correlation between visual viscosity and all three IgG concentrations (IgG mg mL ${ }^{-1}$, \%Brix and $\mathrm{nD}$ values) of all native first colostrum samples (Table 2, Fig. 2: Panels A-C). Similarly, significant correlation was found between dynamic viscosity and $\operatorname{lgG~} \mathrm{mg} \mathrm{mL}^{-1}$, 
\%Brix and IgG nD values of all 40 native first colostrum samples (Table 2, Fig. 2: Panels D-F). It is worth mentioning that the statistical analysis between visual and dynamic viscosity of all native first colostrum showed significant correlation coefficients $\left(r_{\mathrm{s}}=634 ; p<0.001\right)$ using Spearman's rank-order correlation method (Table 2, Fig. 2: Panel G).

\section{Effect of thermal treatments}

After treating colostrum at $60^{\circ} \mathrm{C}$ for $60 \mathrm{~min}$, all 14 watery samples changed to a liquid consistency, while the liquid $(n=17)$ and thick $(n=9)$ samples showed slight to moderate viscosity due to coagulation. Similarly, after treating colostrum at $63.5^{\circ} \mathrm{C}$ for $30 \mathrm{~min}, 13$ liquid and 12 thick colostrum samples formed slight to moderate coagulation, (Table 3). Colostrum pasteurized at $72.0^{\circ} \mathrm{C}$ for $15 \mathrm{~s}$ showed a solid form due to excessive coagulation (Table 3).

The dynamic viscosity of native first colostrum samples $(n=40)$ ranged from 4.9 to $219 \mathrm{cP}$ at $1.0 \mathrm{rpm}$ at $30^{\circ} \mathrm{C}$ for a $1 \mathrm{~min}$ program. After treatment at $63.5^{\circ} \mathrm{C}$ for $30 \mathrm{~min}$, only 28 colostrum samples measured at $1.0 \mathrm{rpm}$ at $30^{\circ} \mathrm{C}$ for $1 \mathrm{~min}$ showed dynamic viscosity, ranging from 5.2 to $310 \mathrm{cP}$. The remaining 12 samples were tested at $0.1 \mathrm{rpm}$ at $30^{\circ} \mathrm{C}$ for $1 \mathrm{~min}$, showing dynamic viscosity ranging from 1.407 to 3066 $\mathrm{CP}$ (Table 1). Statistical analysis of dynamic viscosity values of native first colostrum samples and heattreated samples at $63.5^{\circ} \mathrm{C}$ for $30 \mathrm{~min}$ with $\lg \mathrm{G}$ concentrations showed no significant correlation $(r=0.00)$.

\section{Discussion}

Previous studies have suggested that newborn calves should be fed shortly after birth with an adequate amount of high-quality first-milking colostrum, containing $\geq 50 \mathrm{mg} \mathrm{mL}^{-1}$ of colostrum IgG, to acquire transfer of passive immunity (7-9). In Germany, limited research data are available regarding the FTPI, colostrum IgG quality and influence of thermal treatments on colostrum viscosity. To our knowledge, this is the first detailed study describing the colostrum quality including color gradation, viscosity, fat and IgG concentration of first-milking postpartum dairy cattle colostrum collected randomly from healthy cows from March 2017 to February 2018. Furthermore, this study evaluated the relationship between the impact of heat treatments of colostrum and threshold of IgG on the viscosity of colostrum. In the present study, the second- and third-milking colostrum, the factors impacting the quality of colostrum such as breed, parity, season, dry period length and volume of colostrum were not included $(13,26)$.

Generally, physical properties of colostrum like color gradation and density or viscosity give an initial impression of the quality status of colostrum. For this study, color was assessed visually and ranged from white-pale yellow to yellow and dark-yellow, this gradation of color and degree of viscosity (watery, liquid and thick consistency) showing a significant ( $\mathrm{\otimes} \otimes .05$ ) relationship, respectively. According to Gross et al. (27), measuring the color of cow colostrum might be a new tool to assess quality. The authors reported that colostrum has a wide range of color spectra ranging from pale-white to dark-brown/red compared to the dairy cow milk color. The color gradation of colostrum increased progressively from pale 
to dark with more fat, protein and IgG concentration as well as other factors such as dietary composition being contributory factors (27-29).

In the current study, the fat content varied from 1.4 to $8.8 \%$ with a mean of $5.4 \%$ in contrast to Quigley et al. (30) who reported a higher fat content varying from 9.16 to $31.63 \%$ with a higher mean of $23.56 \%$. On the other hand, Kehoe et al. (31) measured the colostrum fat at an average of $6.7 \%$ compared to $3.55 \%$ (32). A study on multiparous Holstein cows showed that the fat content of colostrum ranged from 2.3 to $12.5 \%$ (26). In contrast to our study, a highly variable fat content from 1.02 to $21.69 \%$ with a mean of 5.6 $\%$ on US dairy farms compared to Danish dairy farms where fat content varied from 0.6 to $14.0 \%$ with a mean of $6.02 \%$ was reported $(33,34)$. However, the present study showed no significant relationship between color gradation and fat content nor between various degrees of viscosity and fat contents, respectively.

Over the past two decades, various research groups have evaluated the accuracy of colostrometer (mg $\mathrm{mL}^{-1}$ ) and refractomter (\%Brix and $\mathrm{nD}$ ) tools either by means of comparison or with radial immunodiffusion (RID) assay used as a gold standard method. A study by Chigerwe et al. (15) compared four methods to assess the IgG concentration in dairy cows and found equal correlation coefficients of the colostrometer and Brix refractometer by comparing 0.76 and 0.75 RID values. On the other hand, Bartier et al. (12), reported that colostrometer values were highly correlated with RID values $(r=0.77)$ compared to RID and Brix refractometer $(r=0.64)$ values. Generally, these tools and the RID assay showed a strong correlation coefficient (from 0.62 to 0.87$)(12,15,19,30,33-38)$. According to Bartier et al. (12), the reasons for variable values of correlation coefficients could be due to variations in the content of non-lgG protein in the colostrum and other factors such as dry period length, vaccination status and season of parturition that affected the concentration of dissolved components. These studies recommended both the colostrometer and refractomter as alternative, indirect, rapid and accurate onfarm tools to provide precise and reproducible results for assessing IgG concentration. Based on the previous data, we used these two indirect tools to estimate the IgG quality of German Holstein dairy cattle colostrum. Both methods showed a high degree of similarity in the classification of colostrum IgG (95\%) concentration and strong correlation coefficients; 0.894 and 0.887 with \%Brix and $\mathrm{nD}$ values, respectively, which is higher than the results reported by Bielmann et al. (35) and Quigley et al. (36) where the correlation coefficients of $\mathrm{IgG}$ and \%Brix were relatively low ( 0.71 and 0.75 , respectively). However, results of our study were similar to those reported by Morrill et al (37) with a correlation coefficient of 0.86 . Colostrum quality in the present study revealed disparate individual IgG concentrations leading to a huge variation ranging from 4 to $116 \mathrm{mg} \mathrm{mL}^{-1}$ with the $58 \mathrm{mg} \mathrm{mL}^{-1}$ mean lower than previously reported (30) where the mean of $\mathrm{IgG}$ concentration was $65.8 \mathrm{mg} \mathrm{mL}^{-1}$. The data of the colostrometer $\left(\mathrm{mg} \mathrm{mL}^{-1}\right)$ and refractomter (\%Brix and $\mathrm{nD}$ ) in the present study revealed that 14 (37.5\%), $17(42.5 \%)$ and $14(37.5 \%)$ samples, respectively did not show similarity to the recommended cut-point ( $\geq 50 \mathrm{mg} \mathrm{mL}^{-1} ; \geq 20 \%$ Brix and $\geq 1.3596 \mathrm{nD}$ ) values. A study on Swedish dairy cows reported high variation in colostrum IgG concentrations ranging from 4 to $235 \mathrm{mg} \mathrm{mL}^{-1}$ with a low median of $45 \mathrm{mg} \mathrm{mL}^{-1}$ and the majority of cows (57.8\%) produced colostrum containing $\operatorname{lgG}<50 \mathrm{mg} \mathrm{mL}^{-1}$ measured by RID assay (39). However, 
Chigerwe et al. (15) found $32 \%$ of colostrum samples to have an inadequate IgG concentration, while Conneely et al. (40) reported that $96 \%$ of colostrum samples contained a IgG concentration $>50 \mathrm{mg}$ of $\mathrm{mL}^{-1}$ with a mean of $112 \mathrm{mg} \mathrm{mL}^{-1}$ measured by ELISA. Contrary to our study results, Morrill et al. (33) reported a higher concentration of IgG in colostrum ranging from $<1$ to $200 \mathrm{mg} \mathrm{mL}^{-1}$ with a mean of 68.8 $\mathrm{mg} \mathrm{mL}^{-1}$ and $\sim 30 \%$ of colostrum containing $<50 \mathrm{mg} \mathrm{mL}^{-1}$ of IgG. On the other hand, a $72.91 \mathrm{mg} \mathrm{mL}^{-1}$ mean IgG concentration was determined by RID in fresh colostrum of Jersey dairy cattle ranging from 12.82 to $154.26 \mathrm{mg} \mathrm{mL}^{-1}$, and $32.75 \%$ of samples had $<50 \mathrm{mg} \mathrm{mL}^{-1}$ of $\mathrm{lgG}$ with a mean \%Brix of fresh colostrum being $21.24 \%$, \% Brix values ranging from $10.5 \%$ to $28.6 \%$ with recommended breed-specific cut points of $\geq 18 \%$ (37). In congruence with our \%Brix value results, conventional (62.5\%) and organic (56.1\%) Danish dairy cattle colostrum samples had equal or exceeded cut-points of $22 \%$ Brix, with significant variation in ranging from $8.3 \%$ to $35.1 \%$ (13). A study conducted on colostrum samples of different Danish dairy cow breeds showed variation from 3 to $154 \mathrm{mg} \mathrm{mL}^{-1}$ of IgG concentration with an average value of $60.2 \mathrm{mg} \mathrm{mL}^{-1}$ (34). Elsohaby et al. (18) determined the IgG concentration of the Canadian dairy cows colostrum by RID assay ranging from 4 to $145 \mathrm{mg} \mathrm{mL}^{-1}$ with an average of $48 \mathrm{mg}$ $\mathrm{mL}^{-1}$ and $39 \%$ of the colostrum samples showed good quality with a cut-point $\geq 50 \mathrm{mg} \mathrm{mL}^{-1}$. A further study by Elsohaby et al. (19) measured the colostrum IgG concentration of Canadian dairy cows that showed high values ranging from 8.4 to $232.4 \mathrm{mg} \mathrm{mL}^{-1}$ with a mean $64.7 \mathrm{mg} \mathrm{mL}^{-1}$ using RID assay and $48 \%$ of samples contained IgG lower than a cut-point of $50 \mathrm{mg} \mathrm{mL}^{-1}$. Determining the cut-point level for good quality colostrum by means of the Brix refractometer was previously studied $(15,35,36,34,38)$. Our cut-point level of good quality colostrum was determined at $\geq 20 \%$ Brix corresponding to IgG concentration $\geq 50 \mathrm{mg} \mathrm{mL}^{-1}$ of colostrometer results. Chigerwe et al. (15) and Bielmann et al. (35) suggested $22 \%$ Brix as an optimal cut-point level compared to levels of $18 \%, 21 \%$ and $23 \%$ recommended for Jersey dairy cattle colostrum $(12,34,36-38,42)$.

Heat treatment of colostrum either in laboratory conditions or directly on the farm using a commercial batch pasteurization system was previously investigated to determine the efficiency of pasteurization on viability of microorganisms to reduce calf exposure to bacterial pathogens, change in viscosity (degree of coagulation) and degradation of $\lg G(11,25,42)$. The present study indicates that pasteurizing colostrum at $60^{\circ} \mathrm{C}$ for 60 min containing $\otimes 80 \mathrm{mg} \mathrm{mL}^{-1}$ of IgG concentration may have a minimal impact on the viscosity, whilst pasteurizing colostrum at $63.5^{\circ} \mathrm{C}$ for 30 min containing

\68 $\mathrm{mg} \mathrm{mL}^{-1} \mathrm{IgG}$ concentration may have a moderate impact on the viscosity. Our study results correspond to the previous study where pasteurizing colostrum at $63.5^{\circ} \mathrm{C}$ for $30 \mathrm{~min}$ using a commercial batch pasteurizer produced a mildly thick coagulation consistency compared to $72^{\circ} \mathrm{C}$ for $15 \mathrm{~s}$ where heattreatment caused a solid form of colostrum especially in samples containing

IgG $>50 \mathrm{mg} \mathrm{mL}^{-1}$ concentration (11). Furthermore, viscosity or IgG concentration remained unaltered when colostrum was treated at $60^{\circ} \mathrm{C}$ for 120 min using the Rapid Visco Analyzer (RVA). However, high quality colostrum containing $\geq 73.0 \mathrm{mg} \mathrm{mL}-1 \mathrm{lgG}$ concentration had a significant impact on lgG concentration and viscosity at $63^{\circ} \mathrm{C}$ compared with colostrum containing $<73.0 \mathrm{mg} \mathrm{mL}^{-1} \mathrm{lgG}$ 
concentration (24). Similarly, no change in IgG concentration was observed when colostrum was treated at $60^{\circ} \mathrm{C}$ for 60 min using a commercial on-farm batch pasteurizer (43). Interestingly, similar to our findings, colostrum containing $>50 \mathrm{mg} \mathrm{mL}^{-1} \mathrm{IgG}$ was treated at various temperatures $\left(57,60\right.$ and $\left.63^{\circ} \mathrm{C}\right)$ and times (30,60 and $90 \mathrm{~min}$ ) using a water bath where colostrum treated at $60^{\circ} \mathrm{C}$ for 30 or $60 \mathrm{~min}$ slightly reduced IgG concentration and did not affect viscosity (25). Donahue et al. (44) reported firstmilking colostrum containing IgG between $97.4-36.4 \mathrm{mg} \mathrm{mL}^{-1}$ treated at $60^{\circ} \mathrm{C}$ for 60 min not showing a negative impact on IgG concentration. Nonetheless, change in the viscosity of colostrum containing IgG $\geq 80 \mathrm{mg} \mathrm{mL}^{-1}$ was not reported. Similarly, pasteurization of first colostrum of buffaloes and cows was carried out at $63^{\circ} \mathrm{C}$ for $30 \mathrm{~min}, 60^{\circ} \mathrm{C}$ for $60 \mathrm{~min}$ and $72^{\circ} \mathrm{C}$ for $15 \mathrm{~s}$ where no effect on the IgG concentration and viscosity of colostrum was observed at $60^{\circ} \mathrm{C}$ for 60 min compared to a study where no impact on IgG concentration and quality of colostrum treated at $60^{\circ} \mathrm{C}$ and $63^{\circ} \mathrm{C}$ for 30 and 60 min was observed $(38,45)$.

\section{Conclusion}

This study provides information on in-situ use of colostrometer or digital refrectometer for quantitative analysis of IgG concentration of first colostrum and suggests that this assay is useful prior to initiating the colostrum pasteurization step. The treatment of colostrum containing IgG concentration of $\leq 80 \mathrm{mg}$ $\mathrm{mL}^{-1}$ at $60^{\circ} \mathrm{C}$ for 60 min did not change the viscosity and can successfully be applied to pasteurize colostrum. Alternatively, treatment at an optimal temperature of $63.5^{\circ} \mathrm{C}$ and time of $30 \mathrm{~min}$ containing IgG concentration $\otimes 68 \mathrm{mg} \mathrm{mL}^{-1}$ may also be used to pasteurize colostrum, having a minimal impact on the viscosity. Overall, the treatments subsequently allow to adjust the volume of colostrum for feeding for a successful transfer of passive immunity to the calves.

\section{Methods}

\section{Selection of dairy cattle herds and sample collection}

Initially, 16 eligible German Holstein dairy cattle farms, located in the federal state of Hessen, Germany, were selected for the colostrum sample collection. A written informed consent from the Klinik für Geburtshilfe, Gynäkologie und Andrologie der Groß- und Kleintiere mit Tierärztlicher Ambulanz, JustusLiebig-University Gießen has been obtained to use the animals in this study. This study has been submitted to and approved by the Regierungspräsidium Gießen,number:

V54-19 c2015 h01.

A total of 40 colostrum samples from dairy cattle aged between three and seven years taken immediately after parturition were collected from March 2017 to October 2018. The first colostrum was hand-milked by farmers or veterinarians, each animal yielding between 2-3 liters. The newborn calves were not allowed to suckle on the udder prior to the sample collection. Samples were aliquoted in 1-liter sterile polypropylene bottles $\left(\mathrm{VWR}^{\circledR}{ }^{\circledR}\right.$, Darmstadt, Germany). The samples were labeled with the name of the 
farm, cow identification number, date of collection, color of colostrum and parturition status (normal, caesarean section and dystocia). Samples were placed on ice in a cooler and transported to the Laboratory of Obstetrics, Gynecology, Andrology of Large and Small Animals Clinic with Veterinary Ambulance, University of Giessen (Klinik für Geburtshilfe, Gynäkologie und Andrologie der Groß- und Kleintiere mit Tierärztlicher Ambulanz, Justus-Liebig-Universität Gießen) for analyses. One liter of fresh colostrum sample was gently homogenized and analyzed for IgG concentration. In addition, $10-20 \mathrm{~mL}$ of each sample was stored at $-20^{\circ} \mathrm{C}$ until further analysis.

\section{Color, viscosity and fat content}

Each freshly collected colostrum sample was visually analyzed for color and viscosity. The viscosity was categorized into three types: watery, liquidy and thick. After heat treatment of colostrum, the visual viscosity was categorized into five types: liquidy, liquidy - slightly to moderately coagulated, thick, thick slightly to moderately coagulated and solid. Dynamic viscosity of native first colostrum samples was determined using a viscometer DV3T touch screen rheometer (AMETEK Brookfield, Lorch, Germany) at 1 $\mathrm{rpm}$ at $30^{\circ} \mathrm{C}$ for $1 \mathrm{~min}$ in accordance with the manufacturers' instructions. Similarly, the dynamic viscosity of heat-treated colostrum samples processed at $63.5^{\circ} \mathrm{C}$ for $30 \mathrm{~min}$ was also analyzed at $1 \mathrm{rpm}$ at $30^{\circ} \mathrm{C}$ for $1 \mathrm{~min}$ and at $0.1 \mathrm{rpm}$ at $30^{\circ} \mathrm{C}$ for $1 \mathrm{~min}$ depending on the degree of viscosity. Each $20 \mathrm{~mL}$ of colostrum sample was thawed in a water bath and homogenized. Afterwards, $10.75 \mathrm{~mL}$ was used to determine total fat (\%) concentration in accordance with the Gerber method performed at the Analytical Chemistry Laboratory of Landesbetrieb Hessisches Landeslabor (LHL), Gießen, Germany.

\section{IgG concentration}

The specific gravity or density of colostrum Ig content $\left(\mathrm{mg} \mathrm{mL}^{-1}\right)$ was measured by a colostrometer (14, 46), with an optimum temperature of $37^{\circ} \mathrm{C}$ in accordance with the manufacturers' instructions (Pfizer Animal Health $\mathrm{GmbH}$, Berlin, Germany). Briefly, one liter of freshly collected colostrum was equilibrated to a temperature of $37^{\circ} \mathrm{C}$ in the water bath for 1 to $2 \mathrm{~h}$, and $\sim 500 \mathrm{~mL}$ of gently mixed sample was transferred to the colostrometer measuring cylinder. The colostrometer was gently inserted and floated to a level indicating the colostrum IgG concentration. As shown on the colostrometer, the specific gravity of colostrum IgG concentration ( $\mathrm{mg} \mathrm{mL}^{-1}$ ) was determined based on the grades including good quality (110-51 $\mathrm{mg} \mathrm{mL}^{-1}$ [green]); questionable quality (50-21 $\mathrm{mg} \mathrm{mL}^{-1}$ [yellow]); and insufficient or poor quality $\left(20-0 \mathrm{mg} \mathrm{mL}^{-1}[\right.$ red]).

Digital refractometer was used as a second method for measuring IgG concentration of fresh colostrum (15). A digital handheld refractometer DR201-95 was used to determine the Brix units (\%Brix) and refractive index $(\mathrm{nD})$ in accordance with the manufacturer's instructions (A. Krüss Optronic, Hamburg, Germany). The refractometer has a wide measuring range of refractive index and sugar scale as well as an ability to automatically compensate temperature. A few drops of fresh homogenized sample were placed on the refractometer prism well and Brix scale (\%Brix) and nD values were recorded. The assay 
was repeated twice in order to minimize errors and values were recorded. The Brix refractometer scale of $\geq 20 \%$ Brix value corresponds to a good quality colostrum with $50 \mathrm{mg} \mathrm{mL}^{-1} \mathrm{lgG}$ concentration compared to $\leq 20 \%$ Brix value which is considered as a low quality.

\section{Thermal treatments}

Thermal treatment was performed in a water bath where colostrum was treated at different temperatures and times including $60^{\circ} \mathrm{C}$ for $60 \mathrm{~min}, 63.5^{\circ} \mathrm{C}$ for $30 \mathrm{~min}$ and $72.0^{\circ} \mathrm{C}$ for $15 \mathrm{~s}(25,38)$. The water bath was calibrated and adjusted to $\pm 0.5^{\circ} \mathrm{C}$ with an additional digital thermometer (Testo 112 Type NTC, Lenzkirch, Germany) and thermometer type UT330A (Reichelt Elektronik GmbH \& Co. KG, Sande, Germany). For the analysis, $2 X 10 \mathrm{~mL}$ of each colostrum sample was treated at each specific temperature and time separately. The colostrum samples were treated without being batched to compare the results of each sample before and after the treatment. The Testo 112 thermometer probe was inserted in the control colostrum sample and values were recorded at one minute intervals throughout the experiment. Simultaneously, a second digital thermometer, type UT330A, was submerged in a water bath to record the deep water temperature and values of the USB Datalogger UT330A thermometer were analysed using the software UNI-T330A in accordance with the manufacturer's instructions (Reichelt Elektronik GmbH \& Co. $\mathrm{KG}$ ). After each treatment, samples were cooled down to $20^{\circ} \mathrm{C}$ and analyzed for visual and dynamic viscosity.

\section{Statistical data analysis}

The statistical data analysis was performed using the statistical software packages BMDP, release 8.1 (47) and StatXact, version 9.0.0 (48). The values are described as arithmetic mean and standard deviation (mean $\pm \mathrm{SD}$ ). The Pearson correlation coefficient $(r)$ and the rank correlation coefficient analysis were performed for ordinal scaled data in accordance with Spearman's $\left(r_{\mathrm{s}}\right)$ and logarithmic methods in order to analyze the relationship between fat concentration, visual viscosity, dynamic viscosity and IgG ( $\mathrm{mg} \mathrm{mL}^{-1}, \%$ Brix and $\mathrm{nD}$ ) values. Additionally, a regression equation was generated. $\mathrm{P}<0.05$ was set as the level of significance.

\section{Abbreviations}

Igs: immunoglobulins; IgG: immunoglobulin G; $n D$ : refractive index; $c P$ : centipoise; $C F U$ : colony-forming unit; FTPI: failure of transfer of passive immunity; RID: radial immunodiffusion assay; ELISA: enzymelinked immunosorbent assay; IR: infrared spectroscopy; TIA: turbidimetric immunoassay; RVA: Rapid Visco Analyzer; $(r)$ : Pearson correlation coefficient; $\left(r_{s}\right)$ : Spearman's correlation coefficient; $L H L$ : Landesbetrieb Hessisches Landeslabor.

\section{Declarations}


- Ethics approval and consent to participate

A written informed consent from the Klinik für Geburtshilfe, Gynäkologie und Andrologie der Groß- und Kleintiere mit Tierärztlicher Ambulanz, Justus-Liebig-University Gießen has been obtained to use the animals in this study. This study has been submitted to and approved by the Regierungspräsidium Gießen, number: V54-19 c2015 h01. Also the same institute has a consent from farm owners to collect the samples from dairy cows all over the time of project.

- Consent for publication

Not applicable.

- Funding

This study is a part of the project: Validation and establishment of a novel pasteurization process for first milking bovine colostrum to reduce Mycobacterium avium subsp. paratuberculosis (MAP) -minimization strategy for dairy herds. The project was totally funded by the Bundesministerium für Ernährung, Landwirtschaft und Verbraucherschutz über das Zweckvermögen des Bundes bei der Landwirtschaftlichen Rentenbank (LR) under Project \#: 819589.

- Availability of data and material

Not applicable

- Competing Interest

The authors declare that they have no conflict of interest.

- Authors contributions

AAH, SG and FS proposed and designed the experiment, collected and analyzed samples. KF performed statistical data analysis. AW, IK, AA and MB drafted and reviewed the manuscript. All authors read and approved the final manuscript.

- Acknowledgments

We would like to thank the farm owners for their participation and untiring help and support to conduct this study. Also, we would like to thank Dr. Manuela Fischer-Zorn from (LHL), Gießen, Germany for her assistance with laboratory analysis.

\section{References}

1. Bernabucci U1, Basiricò L, Morera P. Impact of hot environment on colostrum and milk composition. Cell Mol Biol. 2013;59:67- 
2. Larson BK, Heary HK, Devery JE. Immunoglobulin Production and Transport by the Mammary Gland. Journal of Dairy Sci. 1980; 63:665-71.

3. Godden S. Colostrum Management for Dairy Calves. Vet Clin Food Anim. 2008:24;1939.

4. McGrath BA, Patrick FF, McSweeney PLH, Kelly AL. Composition and properties of bovine colostrum: a review Brian. Dairy Sci. \& Technol. 2016;96:133-

5. Ganz S, Bülte M, Gajewski Z, Wehrend A. Inhaltsstoffe des bovinen Kolostrums - Eine Übersicht. Tierarztl Prax Ausg G. 2018;46:178-89.

6. Fischer AJ, Song Y, He Z, Haines DM, Guan LL, Steele MA. Effect of delaying colostrum feeding on passive transfer and intestinal bacterial colonization in neonatal male Holstein calves. J Dairy Sci. 2018;101:3099-109.

7. Vogels Z, Chuck GM, Morton JM, Failure of transfer of passive immunity and agammaglobulinaemia in calves in south-west Victorian dairy herds: prevalence and risk factors. Aust Vet J. 2013;91,150-

8. Lora I, Barberio A, Contiero B, Paparella P, Bonfanti L, Brscic M, Stefani AL, Gottardo F. Factors associated with passive immunity transfer in dairy calves: combined effect of delivery time, amount and quality of the first colostrum meal. 2018;12:1041-49.

9. Elsohaby I, McClure JT, Waite LA, Cameron M, Heider LC, Keefe GP. Using serum and plasma samples to assess failure of transfer of passive immunity in dairy calves. J Dairy Sci. 2019;102:567-77.

10. McGuirk SM, Collins M. Managing the production, storage, and delivery of colostrum. Vet Clin Food Anim. 2004;20:593-03.

11. Godden SM, Smith S, Feirtag JM, Green LR, Wells SJ, Fetrow JP. Effect of on-farm commercial batch pasteurization of colostrum on colostrum and serum immunoglobulin concentrations in dairy calves. J Dairy Sci. 2003;86:1503-12.

12. Bartier AL, Windeyer MC, Doepel L. Evaluation of on-farm tools for colostrum quality measurement. J Dairy Sci. 2015;98:1878-

13. Mejer, T. Bovine colostrum and factors impacting colostrum quality in conventional and organic dairy herds. Master thesis. Aarhus University. Denmark. 2015. pp. 1-

14. Fleenor, WA, Stott GH. Hydrometer test for estimation of immunoglobulin concentration in bovine colostrum. J Dairy Sci. 1980;63:973-77.

15. Chigerwe M, Tyler JW, Schultz LG, Middleton JR, Spain JN, Dill JS, Steevens BJ. Comparison of four methods to assess colostral IgG concentration in dairy cows. J Am Vet Med Assoc. 2008;233:761-66.

16. McBeath DG, Penhale WJ, Logan EF. An examination of the influence of husbandry on the plasma immunoglobulin level of the newborn calf, using a rapid refractometer test for assessing immunoglobulin content. Vet Rec.1971;88:266-70. 
17. Gelsinger SL, Jones CM, Heinrichs AJ. Effect of colostrum heat treatment and bacterial population on IgG absorption and health of neonatal calves. J Dairy Sci, 2015;98:4640e4645.

18. Elsohaby I, McClure JT, Riley CB, Shaw RA, Keefe GP. Quantification of bovine immunoglobulin $\mathrm{G}$ using transmission and attenuated total reflectance infrared spectroscopy. J Vet Diagn Invest. 2016;28:30-37.

19. Elsohaby I, McClure JT, Cameron M, Heider LC, Keefe G P. Rapid assessment of bovine colostrum quality: How reliable are transmission infrared spectroscopy and digital and optical refractometers?. J Dairy Sci. 2017;100:427-35.

20. Etzel LR, Strohbehn RE, McVicker JK. Development of an automated turbidometric immunoassay for quantification of bovine serum immunoglobulin G. Am J Vet Res. 1997;58:1201-05.

21. Drikic M, Windeyer C, Olsen S, Fu Y, Doepel L, De Buck J. Determining the IgG concentrations in bovine colostrum and calf sera with a novel enzymatic assay. J Anim Sci Biotechnol. 2018;9:69.

22. Phipps AJ, Beggs DS, Murray AJ, Mansell PD, Stevenson MA, Pyman MF. Survey of bovine colostrum quality and hygiene on northern Victorian dairy farms. J Dairy Sci. 2016;99:8981-

23. Tacoma R, Gelsinger SL, Lam YW, Scuderi RA, Ebenstein DB, Heinrichs AJ, Greenwood SL. Exploration of the bovine colostrum proteome and effects of heat treatment time on colostrum protein profile. J Dairy Sci. 2017;100:9392-

24. McMartin S, Godden S, Metzger L, Feirtag J, Bey R, Stabel J, Goyal S, Fetrow J, Wells S, Chester-Jones H. Heat treatment of bovine colostrum. I: effects of temperature on viscosity and immunoglobulin G level. J Dairy Sci. 2006;89:2110-

25. Elizondo-Salazar J, Jayarao B, Heinrichs A. Effect of heat treatment of bovine colostrum on bacterial counts, viscosity, and immunoglobulin G concentration. J Dairy Sci. 2010;93: 96167.

26. Morin DE, Constable PD, Maunsell FP, McCoy GC. Factors associated with colostral specific gravity in dairy cows. J. Dairy Sci. 2001;84:937-43.

27. Gross JJ, Kessler EC, Bruckmaier RM. Colour measurement of colostrum for estimation of colostral IgG and colostrum composition in dairy cows. J Dairy Res. 2014;81:440-4

28. Madsen BD, Rasmussen MD, Nielsen MO, Wiking L, Larsen LB. Physical properties of mammary secretions in relation to chemical hanges during transition from colostrum to milk. J Dairy Res. 2004;71:263-72.

29. Solah VA, Staines V, Honda S, Limley HA. Measurement of milk color and composition: effect of dietary intervention on western Australian Holstein-Friesian cow's milk quality. J Food Sci. 2007;72 S560-S66. 
30. Quigley, JD III, Martin KR, Dowlen HH, Wallis LB, Lamar K. Immunoglobulin concentration, specific gravity, and nitrogen fractions of colostrum from Jersey cattle. J Dairy Sci. 1994;77:264-69.

31. Kehoe SI, Jayarao BM, Heinrichs AJ. A survey of bovine colostrum composition and colostrum management practices on Pennsylvania dairy farms. J Dairy Sci. 2007;90:4108-16.

32. Tsioulpas A, Grandison AD, Lewis MJ. Changes in physical properties of bovine milk from the colostrum period to early lactation. J Dairy Sci. 2007;90:5012-17.

33. Morrill K M, Conrad EM, Lago A, Campbell J, Quigley J, Tyler H. Nation-wide evaluation of quality and composition of colostrum on dairy farms in the United States. J Dairy Sci. 2012;95:3997-05.

34. Løkke MM, Engelbrecht R, Wiking L. Covariance structures of fat and protein influence the estimation of IgG in bovine colostrum. J Dairy Res. 2016;83:58-

35. Bielmann V, Gillan J, Perkins NR, Skidmore AL, Godden S, Leslie KE. An evalution of Brix refractometry instruments for measurement of colostrum quality in dairy cattle. J. Dairy Sci. 2010;93:3713-

36. Quigley JD, Lago A, Chapman C, Erickson P, Polo J. Evaluation of the Brix refractometer to estimate immunoglobulin G concentration in bovine colostrum. J Dairy Sci. 2013;96:114855.

37. Morrill KM, Robertson KE, Spring MM, Robinson AL, Tyler HD. Validating a refractometer to evaluate immunoglobulin G concentration in Jersey colostrum and the effect of multiple freeze-thaw cycles on evaluating colostrum quality. J Dairy Sci. 2015;98:595-

38. Elsohaby I, McClure JT, Dow N, Keefe GP. Effect of heat-treatment on accuracy of infrared spectroscopy and digital and optical Brix refractometers for measuring immunoglobulin G concentration in bovine colostrum. J Vet Intern Med. 2018;32:49196.

39. Gulliksen SM, Lie KI, Sølverød L, Østerås O. Risk factors associated with colostrum quality in Norwegian dairy cows. J Dairy Sci. 2008;91:704-712.

40. Conneely M, Berry DP, Sayers R, Murphy JP, Lorenz I, Doherty ML, Kennedy E. Factors associated with the concentration of immunoglobulin $\mathrm{G}$ in the colostrum of dairy cows. 2013;7:1824-32.

41. Bartens M-C, Drillich M, Rychli K, Iwersen M, Arnholdt T, Meyer L, Klein-Jöbstl D. Assessment of different methods to estimate bovine colostrum quality on farm. N Z Vet J. 2016;64:263-67. 
42. Green L, Godden S, Feirtag J. Effect of batch and high temperature-short time pasteurization on immunoglobulin G concentrations in colostrum. J Dairy Sci. 2003;86:246.

43. Johnson JL, Godden SM, Molitor T, Ames T, Hagman D. Effects of feeding heat-treated colostrum on passive transfer of immune and nutritional parameters in neonatal dairy calves. J Dairy Sci. 2007;90:5189-98.

44. Donahue M, Godden SM, Bey R, Wells S, Oakes JM, Sreevatsan S, Stabel J, Fetrow J. Heat treatment of colostrum on commercial dairy farms decreases colostrum microbial counts while maintaining colostrum immunoglobulin G concentrations. J Dairy Sci. 2012;95:2697-702.

45. Abd El-Fattah AM, Abd Rabo FH, El-Dieb SM, El-Kashef HA. Changes in composition of colostrum of Egyptian buffaloes and Holstein cows. BMC Vet Res. 2012;5:8:19.

46. Pritchelt LC, Gay CC, Hancock DD, Besser TE. Evaluation of the hydrometer for testing immunoglobulin G1 concentrations in Holstein colostrum. J Dairy Sci. 1994;77:1761-67.

47. Dixon WJ (chief editor). BMDP Statistical Software Manual. University of California Press, Berkeley, Los Angeles, London. Volume 1 and 2. 1993.

48. Cytel Studio StatXact Vers. 9.0.0. Statistical Software for Exact Nonparametric Inference, User Manual. 2010. CYTEL Inc., Cambridge, MA 02139, U.S.A.

\section{Tables}

\section{Table 1}

\begin{tabular}{llllll}
\hline Parameter & Mean (average) & Median & \pm SD & Minimum & Maximum \\
\hline Fat (\%) & 5.41 & 5.55 & 2.03 & 1.4 & 8.8 \\
IgG $\left(\mathrm{mg} \mathrm{mL}^{-1}\right)$ & 57.65 & 63.0 & 32.71 & 4 & 116 \\
\%Brix & 20.32 & 20.35 & 6.12 & 8.5 & 35.4 \\
$\mathrm{nD}$ & 1.3640 & 1.3630 & 0.010 & 1.3454 & 1.3905 \\
Dynamic viscosity (cP) & 34.55 & 20 & 41.27 & 4.9 & 219 \\
& & & & & \\
Dynamic viscosity (cP) & 75.8 & 33.5 & 102.65 & 5.2 & 3.066 \\
\hline
\end{tabular}

${ }^{\dagger}$ : native first colostrum; ${ }^{\dagger+}$ : treated colostrum $\left(63.5^{\circ} \mathrm{C}\right.$ for $\left.30 \mathrm{~min}\right)$

\section{Table 2}




\begin{tabular}{|c|c|c|c|c|c|}
\hline Parameter & $\begin{array}{l}\operatorname{IgG} \\
(\mathrm{mg} \\
\left.\mathrm{mL}^{-1}\right)\end{array}$ & \%Brix & $\mathrm{nD}$ & $\begin{array}{l}\text { Visual viscosity of } \\
\text { native first } \\
\text { colostrum }\end{array}$ & $\begin{array}{c}\text { Dynamic viscosity of } \\
\text { native first } \\
\text { colostrum, } \$\end{array}$ \\
\hline Fat\% & $\begin{array}{c}r= \\
0.242 \\
p< \\
0.133\end{array}$ & $\begin{array}{c}r= \\
0.099 \\
p< \\
0.543\end{array}$ & $\begin{array}{c}r= \\
0.081 \\
p< \\
0.619\end{array}$ & $\begin{array}{l}r_{\mathrm{S}}=-203 \\
p<0.210\end{array}$ & $\begin{array}{l}r=0.237 \\
p<0.140\end{array}$ \\
\hline $\operatorname{IgG}\left(\mathrm{mg} \mathrm{mL}^{-1}\right)$ & - & $\begin{array}{c}r= \\
0.894 \\
p< \\
0.001\end{array}$ & $\begin{array}{c}r= \\
0.887 \\
p< \\
0.001\end{array}$ & $\begin{array}{l}r_{\mathrm{s}}=0.896 \\
p<0.001\end{array}$ & $\begin{array}{l}r=0.575 \\
p<0.001\end{array}$ \\
\hline$\%$ Brix & & - & $\begin{array}{c}r= \\
0.991 \\
p< \\
0.001\end{array}$ & $\begin{array}{l}r_{\mathrm{S}}=0.841 \\
p<0.001\end{array}$ & $\begin{array}{l}r=0.742 \\
p<0.001\end{array}$ \\
\hline $\mathrm{nD}$ & & & - & $\begin{array}{l}r_{\mathrm{s}}=0.839 \\
p<0.001\end{array}$ & $\begin{array}{l}r=0.772 \\
p<0.001\end{array}$ \\
\hline $\begin{array}{l}\text { Visual viscosity of } \\
\text { native first } \\
\text { colostrum }\end{array}$ & & & & - & $\begin{array}{l}r_{\mathrm{S}}=0.634 \\
p<0.001\end{array}$ \\
\hline
\end{tabular}

- : logarithmic values; $p$ value: $\square 0.05$ considered significant; $r$ : correlation coefficient; $r_{\mathrm{s}}$ : Spearman's rank-order correlation

\section{Table 3}

\begin{tabular}{|c|c|c|c|c|c|}
\hline \multirow[t]{2}{*}{$\begin{array}{l}\text { IgG values } \\
\left(\mathrm{mg} \mathrm{mL}^{-1}\right)\end{array}$} & \multirow[t]{2}{*}{ (n) } & \multirow[t]{2}{*}{$\begin{array}{l}\text { Visual viscosity of native first } \\
\text { colostrum (n) }\end{array}$} & \multicolumn{3}{|c|}{$\begin{array}{c}\text { Visual viscosity of colostrum after } \\
\text { treatment }\end{array}$} \\
\hline & & & $\begin{array}{l}60^{\circ} \mathrm{C} / 60 \\
\min (\mathrm{n})\end{array}$ & $\begin{array}{l}63.5^{\circ} \mathrm{C} / 30 \\
\min (\mathrm{n})\end{array}$ & $\begin{array}{l}72^{\circ} \mathrm{C} / 15 \\
\mathrm{~s}(\mathrm{n})\end{array}$ \\
\hline $4-46$ & 15 & $\begin{array}{l}\text { Watery (13); } \\
\text { Liquid (2) }\end{array}$ & $\begin{array}{l}\text { Liquid } \\
\text { (15) }\end{array}$ & Liquid (15) & $\begin{array}{l}\text { Liquid }^{\S} \\
\text { (15) }\end{array}$ \\
\hline $50-78$ & 14 & $\begin{array}{l}\text { Watery (1); } \\
\text { Liquid (13) }\end{array}$ & $\begin{array}{l}\text { Liquid } \\
\text { (14) }\end{array}$ & $\begin{array}{l}\text { Liquid }^{\S} \\
\text { (13); } \\
\text { Thick (1) }\end{array}$ & $\begin{array}{l}\text { Liquid }^{\S} \\
(2) ; \\
\text { Solid* } \\
\text { (12) }\end{array}$ \\
\hline 80-116 & 11 & $\begin{array}{l}\text { Liquid (2); } \\
\text { Thick (9) }\end{array}$ & $\begin{array}{l}\text { Thick }^{\S} \\
(11)\end{array}$ & Thick $^{\S}(11)$ & $\begin{array}{l}\text { Solid* }^{*} \\
(11)\end{array}$ \\
\hline
\end{tabular}


(n): number of samples; ${ }^{\S}$ : samples with slight to moderate coagulation; *: samples with excessive coagulation.

Table legends

\section{Table 1 legend}

Analysis of fat, IgG, \%Brix, refractive index (nD), and dynamic viscosity of 40 colostrum samples.

\section{Table 2 legend}

Correlation coefficient analysis of colostrum samples using various parameters.

\section{Table 3 legend}

Categorization of IgG concentrations $\left(\mathrm{mg} \mathrm{mL}^{-1}\right)$ and visual viscosity of native first colostrum and viscosity of colostrum after different treatments.

\section{Figures}



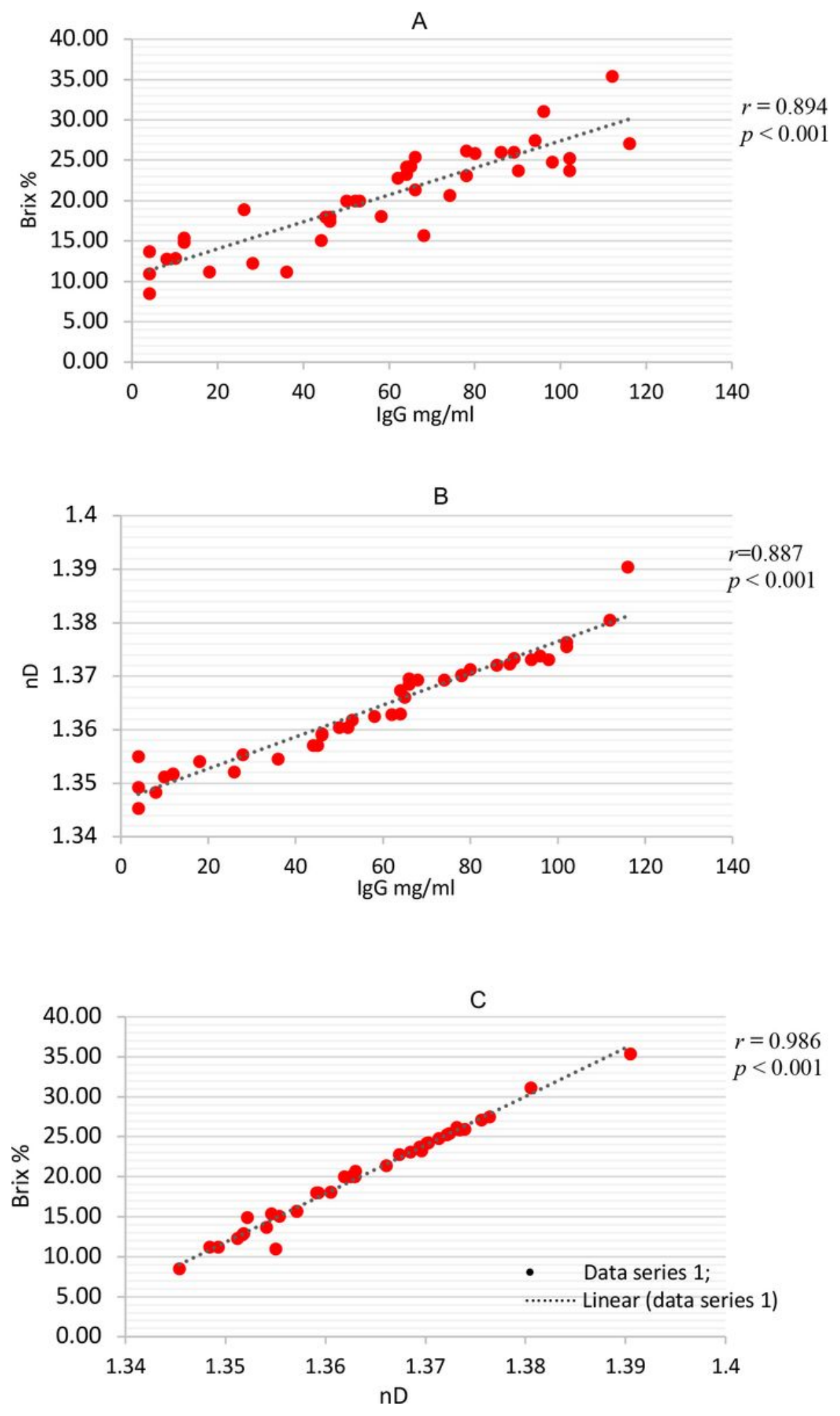

\section{Figure 1}

Correlation analysis of dairy cattle colostrum samples between IgG mg mL-1 and Brix\% (Panel A); IgG mg $\mathrm{mL}-1$ and $\mathrm{nD}$ (Panel B); Brix\% and $\mathrm{nD}$ (Panel C). 

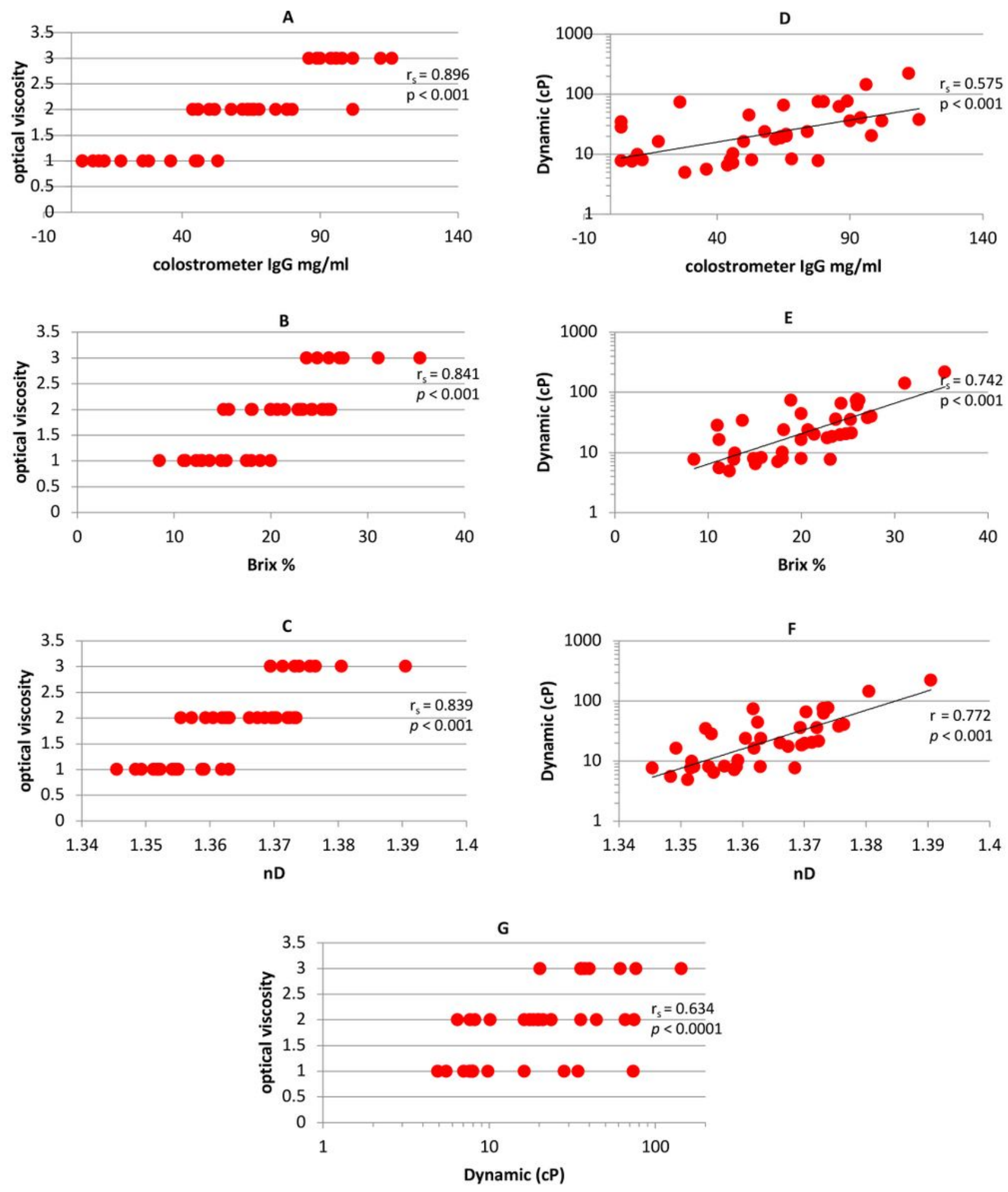

\section{Figure 2}

Panels A, B and C: Correlation analysis of visual viscosity of dairy cattle colostrum with lg $\mathrm{mg} \mathrm{mL}-1$, Brix\% and $\mathrm{nD}$. Panels $\mathrm{D}, \mathrm{E}$ and $\mathrm{F}$ : Correlation analysis of dynamic viscosity with $\mathrm{IgG} \mathrm{mg} \mathrm{mL}-1, \mathrm{Brix} \%$ and $\mathrm{nD}$. Panel G: correlation analysis between visual viscosity and dynamic viscosity.

\section{Supplementary Files}


This is a list of supplementary files associated with this preprint. Click to download.

- figure1.png

- figure2.png 